SPECIAL FEATURE

\title{
Some Professional and Political Events in Canadian Neurosurgery
}

\author{
T.P. Morley
}

Can. J. Neurol. Sci. 1985: 12:230-235

The Hannah Institute for the History of Medicine and Science, with the Royal College's Section on the History of Medicine, asked me for a contribution to the Annual Meeting (1984) in Montreal dealing with the history of Canadian neurosurgery. I soon discovered that the material available to me, from my own files and from colleagues who sent me information, was too extensive for a paper of the required length. I have therefore excluded from this article the balanced review of the scientific and clinical contributions of Canadians in neurosurgery that 1 had hoped to prepare. What remains is a collection of events and developments that have involved or interested me during my career.

\section{Origins of Neurosurgery in Canada}

Neurosurgery in Canada began as an acknowledged specialty in 1923 with the appointment of K.G. McKenzie to the Department of Surgery in the University of Toronto and the Toronto General Hospital. McKenzie's qualification rested upon the twelve months he spent in Boston as house surgeon to Cushing who had accepted him on the recommendation of Professor C.L. Starr in Toronto. Cushing used an award he had received from the Mickle Foundation in Toronto to remunerate McKenzie during his time in Boston.

Urology was the first surgical specialty to be established at the University of Toronto, neurosurgery the second. McKenzie (1960) somewhat mischieviously suggested that it wasn't until Professor Archibald, on a visit to Toronto, saw him operating on the Gasserian ganglion for trigeminal neuralgia that he decided it was time for McGill to recognize the specialty also. Archibald himself, although a general surgeon, was no stranger to the surgery of the nervous system. As Feindel (1967) informs us, Archibald (1908) had made substantial contributions to the neurosurgical literature, in particular his section on surgical affections and wounds of the head in Bryant and Buck's American Practice of Surgery. His decision to create a major neuroscience establishment at McGill was probably at least partly inspired by that vigorous rivalry between Montreal and Toronto which continues to this day. Penfield, with William Cone, came to Montreal in 1928. In 1934 the Montreal Neurological Institute was opened.

Until after the Second World War, Montreal and Toronto were the only two Canadian university centres where neurosurgical specialty training could be obtained. From the beginning, however, the character of each was different from the other. McGill created an Institute with a large measure of autonomy within the University and the teaching hospitals. A feature of the building itself that Penfield insisted was necessary to secure and preserve the autonomy of the Institution, was its physical separation from the adjacent Royal Victoria Hospital. The covered footbridge that connected them was his only concession to visible collegiality. Even that was almost denied him in those depression years, in the name of economy (Penfield, 1976).

Penfield's highest priority was neuroscience research. He accumulated around him like-minded investigators in the related neurosciences and so established the pre-eminent Montreal Neurological Institute.

Cone was an essential ingredient in Penfield's personal success. Through his main interest in surgical practice Cone released Penfield for his research and writing while he bore the brunt of patient care and resident teaching, responsibilities later shared with Arthur Elvidge. The sustained investigations into human epilepsy by Penfield, Jasper, and Rasmussen formed the core of the MNI's fame. Their reputation rested on meticulously recorded observations and imaginative objectives during the course of the fundamental if mundane necessity of treating intractable epilepsy. The fact that surgical treatment of epilepsy was never widely adopted outside that institution did not diminish the original plan for a centre of excellence in neurological research. Even the vitriolic rebuttal by FMR Walshe (1957) of Penfield's hypothesis of centrencephalic epilepsy failed to tarnish the reputation of anyone except, possibly, of Walshe himself. Penfield had the enthusiasm of the explorer but he was always uneasy (and later disillusioned) that his investigations, the direction

From the Division of Neurosurgery. University of Toronto and Toronto General Hospital.

Based on a paper given at the annual meeting of the Royal College. Section of History of Medicine and the Hannah Institute. Montreal, 13 September 1984.

Reprint requests to: T.P. Morley, P.O. Box 58. Claremont, Ontario, Canada L0H IEO 
of which, once started, could not be deflected, would fail to reveal the physiological basis of mind. He hints at this foreboding in the last sentences in the preface to "Epilepsy and the Functional Anatomy of the Human Brain" that he and Jasper published in 1953: "We have made an honest record of the working of the human brain in normal and abnormal states; and, even though we may have gone astray in theory and in rationalization, yet we know these observations will stand, and so perhaps lead others to a clearer conception of the truth."

\section{Training and Supply of Neurosurgeons}

Penfield had his origins in the United States. It was therefore natural that most of his early key associates and residents were American. There was also a strong international following at all levels at the MNI, attracted by the excellence of its scientific production.

By contrast, neurosurgery, neurology and related disciplines, developed in Toronto with considerably less éclat, partly because of the retiring personalities of McKenzie and his immediate colleagues, but also because the policy of the Toronto General Hospital - the only adult teaching hospital in the University at the time - as stated in its charter, was to be "a hospital perfectly complete". The resistance to a separate institution was backed up, no doubt, by a lack of financial support of the order that a wealthier McGill with an abundance of private endowment, including a massive grant from the Rockefeller Foundation, could raise.

Concentration upon research and the attraction to the MNI of foreign graduates resulted in a dearth of Canadian-trained neurosurgeons to fill all the imminent openings in Canadian medical schools. The vacuum was to a large extent filled by graduates of the Toronto training programme under E.H. Botterell who, after World War II, succeeded McKenzie as Head of the division. Thus many appointments were made in the years of prosperity and rapid expansion, both within the greatly enlarged Toronto medical school and in the newly created university neurosurgical divisions in Ontario and across the country. It would not be long before plans had to be made to curb the proliferation of graduate neurosurgeons.

Expansion looks after itself; restraint demands a degree of agreement both as to the necessity for it and as to the methods by which it can be achieved. On the whole, Canadian neurosurgeons were successful in their self-imposed task. I think it is correct to say that they were the first group to try to put their house in order.

During the sixties and seventies the proliferation of neurosurgeons in the United States outstripped, as many believed, the real need. The practice of neurosurgery became stratified, subspecialty groups were formed in paediatric and stereotactic neurosurgery, and while major problems and procedures were undertaken in the major centres the more routine and less complicated cases were attended in community hospitals. On the face of it, this evolution towards secondary and tertiary referral centres was natural and desirable. The trouble was that it didn't work out quite according to plan. In many centres the neurosurgeon became the primary physician rather than the consultant. He usurped the function of the family physician. At the same time he was under pressure to accept and retain the major neurosurgical cases of the sort he encountered during his residency but of which, out in practice, he saw too few to keep his skill alive.
Canadian neurosurgeons, not entirely out of self-interest, believed that the country would be best served by retaining the practice of neurosurgery within the medical schools. The volume of clinical material needed for teaching and to preserve and enhance the surgeon's skill would thus be assured, and the essential complex of supporting services would be available. Geographic considerations have led to some relaxation of this policy, but on the whole it has been followed without regret.

The question was debated at length and on several occasions in the Canadian Neurosurgical Society. Although most members agreed on the need to have some limitation on the number of neurosurgical graduates from our training programmes, a few did not. Differences in provincial regulations and requirements also had to be reconciled with the broad intention.

One effective and fairly simple solution the CNS proposed was that the Royal College should determine national and regional neurosurgical requirements and enforce them by the expedient of admitting to the final examination only a sufficient number of candidates to fill the approved posts. Although the Royal College had always exerted a powerful if discreet influence in medical affairs, it did not receive the suggestion with enthusiasm. It preferred not to enter this political arena and consequently turned down the proposal. I still wonder if the College was not mistaken in rejecting the challenge by retreating, a little piously perhaps, behind the smokescreen of academic purity. It missed the opportunity to achieve at the national level objectives so hard to come by from interprovincial agreement. If the profession could not shoulder the responsibility, government certainly would.

We had to fall back, then, on a somewhat nebulous undertaking between the training programme directors to limit the entrants to neurosurgical training. Not surprisingly, this was at best only partially successful. The smaller centres often lacked candidates of suitable quality and in the struggle to function adequately as a community resource their university obligations were in jeopardy. The larger centres, Toronto and Montreal, were less often confronted by a lack of good applicants and, in fact, on several occasions were able to divert promising candidates they had no room for to other university programmes.

Eventually, hard times forced provincial governments to step in and limit the number of resident posts they were prepared to fund. This has been an effective and inevitable restraint, but in the rigidity of its application it hampers Canadian medical schools from training foreign applicants and even candidates from other provinces within the country.

Newly approved training programmes and, particularly, the university neurosurgical services that were straining to reach the standard demanded for approval by the Royal College, to the credit of their directors and to their great inconvenience and personal hardship, resisted applicants, however clinically competent they appeared, who did not have the spark of academic ambition and ability.

The selection of trainees has always been based mainly on intuition, regardless of sociological studies, guidelines, test batteries and multiple interviewers. The final decision rests, as it should, with the specialty programme director, trusting his own assessment of the personal qualities of the applicant. There is no evidence that a majority decision by a committee is more successful in picking winners than a programme director himself after receiving the views of others. 


\section{The Royal College}

By contrast with the United States, where about half the practising neurosurgeons do not hold certification by the American Board of Neurological Surgery, it is impossible to practise a surgical specialty in Canada (except in the Province of Québec) without the specialty certificate of the Royal College of Physicians and Surgeons of Canada. In Québec the specialty certificate of the Province, rather than the Royal College, is the essential requirement. Many specialists have acquired both.

The relationship between the Royal College and the university medical schools has been remarkably harmonious. Universities have shown resentment, from time to time, at what they perceive as an intrusion into their affairs by the Royal College through its insistence on minimum training standards. But the Royal College was founded in 1929 through the efforts of the existing medical schools. The main purpose was to enforce minimum specialty standards uniformly across the country. Since at that time and, to a great extent, today - the officers and council members were leading university teachers, jurisdictional interests were easily reconciled.

In the specialty of neurosurgery, the Royal College exerts its maximum influence at the level of residency training. Universities must comply to the College's minimum requirements or their residents will not be accepted for examination. The Royal College, acting on the recommendation of its Committee on Neurosurgery, stipulates that, as well as a minimum period in clinical neurosurgery, a trainee shall also spend, amongst other rotations, at least six months in clinical neurology. To the sorrow of neurosurgeons and to the impoverishment of Canadian neurology, the Committee on Neurology has not been persuaded that a similar period of tutelage in neurosurgery should be required of the student neurologist.

\section{Matters of Public Concern}

From time to time Canadian neurosurgery has tried to influence government in matters of public health as they relate to neurological disorders. One of the first submissions was written by Dr. Preston Robb (1962) on behalf of the Canadian Neurological Society which then still represented both neurologists and neurosurgeons. It was addressed to the Royal Commission on Health Services and set out in a general but factual manner deficiences in neurologically related services and recommendations for improvement. The report (Vol. 1) of the Royal Commission (1964) favoured the strengthening of services to the psychologically disabled but did not pay much attention to the victims of structural neurological disease.

A committee of the Canadian Neurosurgical Society under Rankin Hay (1967) of Winnipeg made recommendations for the amelioration of head injuries in traffic accidents. Alan Hudson, at the instigation of a provincial cabinet minister, R.G. Elgie, formerly a neurosurgeon, headed a public commission of inquiry into the folly of the newly imported sport of kick boxing. Penfield and his colleagues at McGill, while concentrating on the scientific aspects of epilepsy, exorcised the bogey that, in the perception of the laity, haunts the epileptic patient. At the end of the war E.H. Botterell and A.T. Jousse led the way in North America in the education of the medical profession, government, and the public towards the prevention and supportive treatment of patients with spinal cord injury. A committee of the Canadian Neurosurgical Society, again under the chairmanship of Hay (Lougheed W.M., Bertrand G., and Hay R.K., 1970) and with the co-operation of the Canadian Paraplegic Association, surveyed the state of paraplegic care in Canada. The formation of the Spinal Injuries Centre at Sunnybrook Medical Centre under Tator and the contributions to the epidemiology of spinal injury by the Lyndhurst Hospital group uphold the strong Canadian influence in the subject (Tator C.H. et al., 1984; Geisler W.O. et al., 1983).

More recently neurosurgeons have taken a leading part in the moulding of public and professional attitudes towards the definition and certification of death as it concerns the timing of organ donation and the maintenance of life support systems in the presence of cerebral death. Physicians did not find the question unusually difficult to handle from the ethical, humanitarian or administrative point of view, until the public and its lawyers drew attention to legal uncertainties that arose from the new-found ability to prolong physiological function beyond the "natural" moment of death. In Ontario the initiative to inquire into the implications of artificial life support for organ donation came from H.B. Cotnam, the Supervising Coroner for Ontario. Under the law a coroner's duties began after the death of the patient, not before. But the process of organ transplantation (at that time the kidney was the organ to which these considerations chiefly applied) demands very careful co-ordination between the transplant team, the family, the donor treatment team and the coroner. If this co-operation is not assured the organ may lose its viability from anoxia. The coroner can now be brought into the picture before death is certified so that immediately upon certification he can sanction the necessary autopsy and organ procurement. Under the old statute, however, intervention antemortem by the coroner was not sanctioned by law. Neurosurgeons, by reason of the type and severity of the disorders they encounter, are more involved in the process of organ donation than other specialists.

A Committee of the Medico-Legal Society of Toronto (on which I sat as neurosurgical representative) under the chairmanship of Mr. Horace Krever Q.C. submitted draft legislation to the Law Reform Commission of Ontario which appeared, virtually unaltered, as The Human Tissue Gift Act (1971) of Ontario. The main stipulations were (1) that organs shall not be bought and sold, (2) that the team acting on behalf of the recipient shall keep its distance until the donor's team announces that death has been certified and (3) that the certification of death by "at least two physicians" shall be based, not on a series of mandatory tests, but " shall be determined . . . in accordance with accepted medical practice."

The Federal Law Reform Commission urged all Provinces to enact similar legislation.

The concern of neurosurgeons for their part in the use of life support systems and certification of death was reflected in the conference convened by L.P. Ivan in Ottawa in 1980 at the fifteenth Canadian Congress of Neurological Sciences (Ivan L.P., 1981).

Before modern psychopharmaceuticals had been generally adopted there was a period of about fifteen years when surgical prefrontal lobotomy and its variants were held to be the best treatment in certain severe cases of psychological disorder. In Canada neurosurgeons performed the operations at the request of psychiatrists, not on their own initiative. Their additional role was to ensure the symptoms were not structural in origin, masquerading as psychological. The University of Toronto 
lobotomy programme was painstakingly planned and every stage minutely inspected by all members of the team involved - psychiatrist, psychologist, surgeon, social worker, nurse and occupational therapist. The results were published by $A$. Miller (1954) through the Ontario Ministry of Health. A second review from Ontario by McKenzie and Kaczanowski appeared in the Canadian Medical Association Journal of 1964. The reports were neither enthusiastic nor condemnatory: they were honest reports of conscientious attempts to improve treatment in a refractory group of psychological disorders.

Improvements in drug therapy supplanted surgical treatment. Lobotomy for severe emotional and behavioural disturbance virtually disappeared from the neurosurgical repertoire twentyfive years ago.

The insistence of our patients to exert influence on what we do and how we do it has improved the general standard of neurosurgical care. But public concern has not always redounded to the public good. Excessive scrutiny induces excessive caution which may not be to the patient's advantage. Sometimes selfappointed scrutineers, with a cause to champion and careless for the facts, may impede clinical progress by poisoning the intellectual and academic atmosphere that nurtures advance,

For example, in 1973 the Centre for the Study of Psychiatry in Washington, D.C. (Director Dr. Peter R. Breggin, MD), distributed a newsletter headed "Current Psychosurgery in Canada". In it the spectre of widespread and increasing incidence of lobotomies across our country was resurrected at a time when lobotomy had passed into history. Amongst numerous other falsehoods and innuendos, the letter said that "as many as 150 psychosurgical operations including cingulotomy and amygdalotomy are performed each year at the Toronto General Hospital". This sort of wild departure from the facts and its consequent impact on public sensibility has curbed serious research into the treatment of human psychological disorders. The campaign by the same alliance against electroconvulsive therapy is the current equivalent. Therapy is not assessed soberly on its scientific and clinical merits but condemned through the volatile medium of emotional appeal.

\section{The Canadian Congress of Neurological Sciences}

In 1948 neurologists, neurosurgeons, psychiatrists and electroencephalographers together formed the one and only Canadian Neurological Society, with Wilder Penfield as its President. In the 1950 s it became increasingly clear that psychiatry was travelling in a fundamentally differenct direction from the other neurological skills. Psychiatry had been included in the neurological fold because that had been the arrangement in the Commonwealth forces during the Second World War. The Queen Square influence was supreme. Organic neurology seemed more important than psychiatry during war; if you chose to become a psychiatric specialist in the forces you did so only after you had demonstrated your ability in medical neurology. Many neurosurgeons and neurologists to this day think that wasn't such a bad arrangement, but other influences from America were inexorable. No tears were shed on either side over the departure of the psychiatrists.

Psychiatrists who were firmly embedded in neurology stayed with the Neurological Society anyway. Nor was the separation of neurologists from neurosurgeons particularly painful because it was arranged gradually.
In 1959 a Neurological Association and a Neurosurgical Association were at first created as divisions within the Canadian Neurological Society. A period of grace was thus established during which both groups prepared for the final schism in 1964 when the Canadian Neurosurgical Society and the Canadian Neurological Society were formed. Neurosurgeons and neurologists felt the political advantage at once. Each group was now organized to speak for itself at CMA council and on the international scientific stage. For example, representation on the Board of Directors of the Harvey Cushing Society (American Association of Neurological Surgeons) which Drake had worked so hard for, was no longer the business, however routine and predictable, of the Canadian Neurological Society, but was the responsibility of the Canadian Neurosurgical Society itself.

It was the desire of all parties that the annual scientific meeting, to be known as the Canadian Congress of Neurological Sciences, should be attended, as before, by the whole neuroscience community. A liaison committee with representation from the constituent societies was created to organize each annual congress. The President of Congress would alternate between neurological medicine and neurological surgery. The liaison committee was given fairly wide executive authority each year but had no power to establish policy - a constraint it did not always appreciate.

In 1969, the newly formed Canadian Association of Neurological and Neurosurgical Nurses was admitted as a partner in the Annual Congress. Today the Congress is made up of the Canadian Neurosurgical Society, the Canadian Neurological Society, the Canadian Society of Clinical Neurophysiologists, the Canadian Association of Neurological and Neurosurgical Nurses and the Canadian Association for Child Neurology.

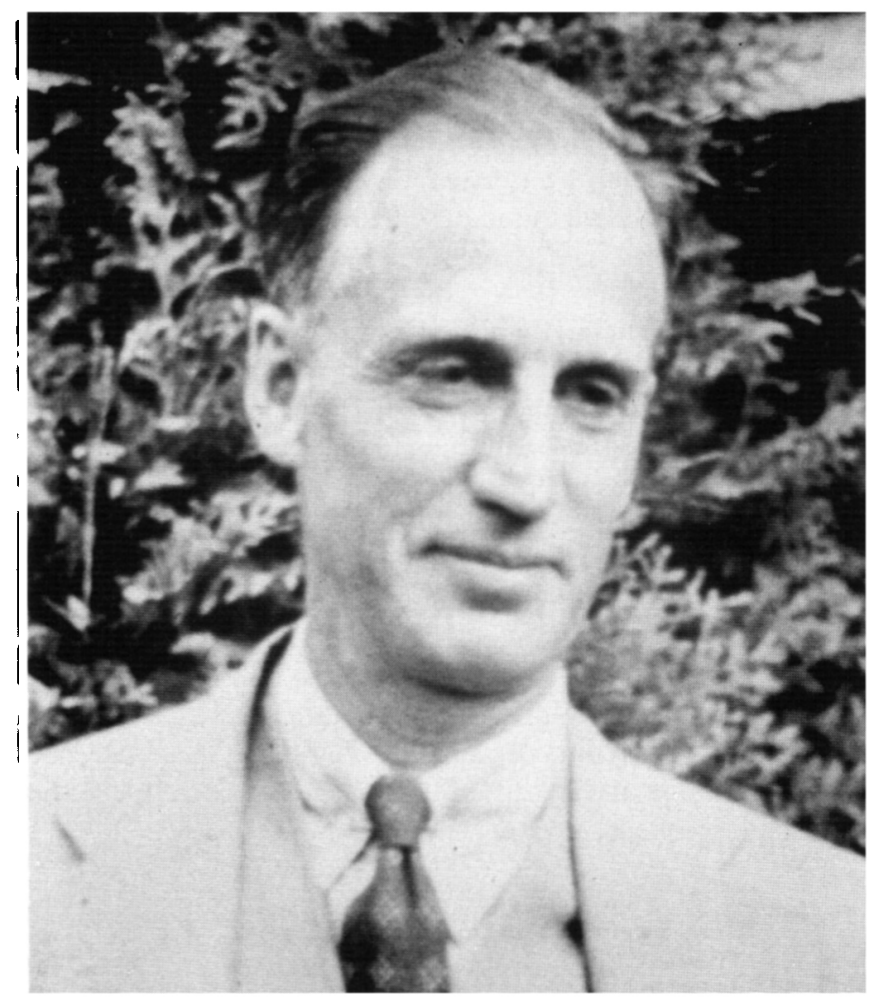

Figure $1-$ K.G. McKenzie 


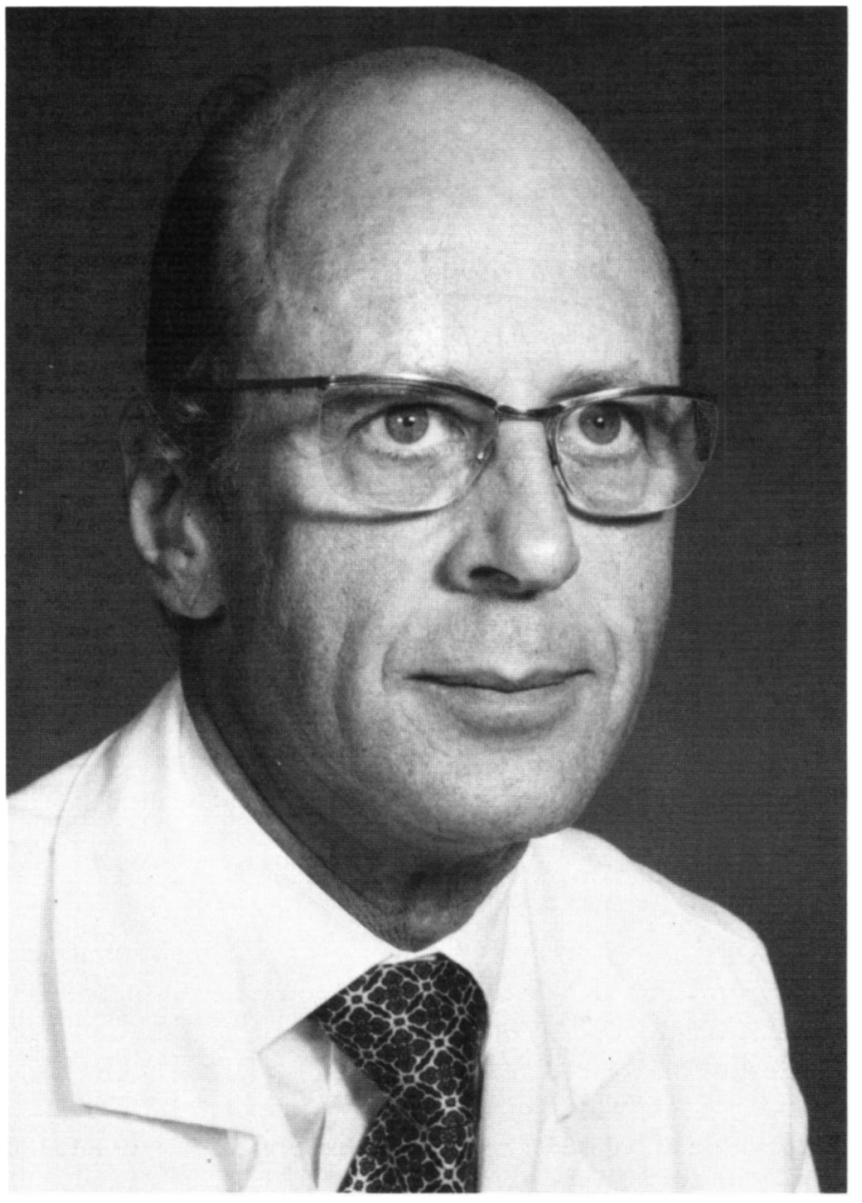

Figure $2-$ R.T. Ross

The Canadian Journal of Neurological Sciences is R.T. Ross's personal triumph and lasting monument. As owner, editor, business and advertising manager, and distributor, he founded the Journal and ran it from his office and his home in Winnipeg. From the beginning he refused to compromise his editorial standards. He fulfilled the requirements for listing in the Index Medicus as a high quality, peer-review journal. The first number came out in February 1974, with the enthusiastic approval of Canadian neuroscientists and clinicians but without their ready support in the form either of articles or subscriptions. After years of struggle under the ever-deepening shadow of personal financial loss he sold the copyright to the Canadian Congress of Neurological Sciences for a dollar. The Journal was saved. Ross bowed out, battered but triumphant. For its dollar (which Ross deposited to the Journal's bank account) the new owners received, in addition to the copyright, the list and goodwill of advertisers, a circulation of 1,500, freedom from debt and unencumbered assets of $\$ 85,000$ cash. Ross continued as editor until his replacement, Robert G. Lee of Calgary was appointed, Lee upholds Ross's editorial standards while the financial solvency of the Journal is underwritten by the member societies of the Canadian Congress.

\section{American Links}

Canadian neurosurgeons have always held it essential to their professional and academic standing to belong to one or

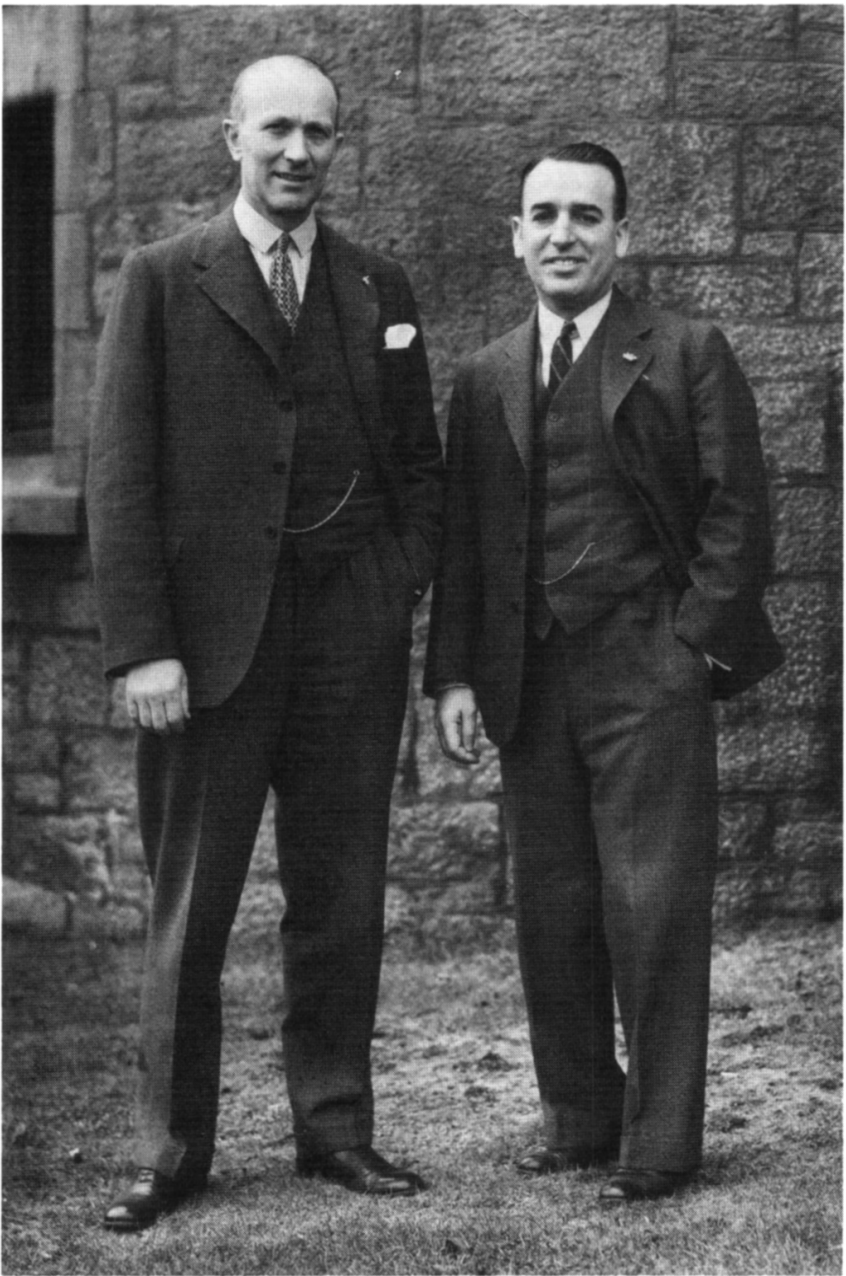

Figure $3-W . P$. Penfield and W.V. Cone

(Courtesy of W. Feindel and Canad. Med. Assoc. J.)

more of the American societies. There has been a tendency in recent years to belong to too many - the number of societies proliferates with growth of the neurosurgical population. To an increasing extent the Canadian Congress fulfills the function of American societies but it will never completely take their place. As Canadians our status in American neurosurgical societies is unique; no discrimination is exercised against us as foreigners. We have the same access to membership as any American. No other country is so favoured. This equality is reflected in the presidencies of U.S. neurosurgical societies held by Canadians, not to mention vice-presidencies.

\section{NAME SOCIETY}

YEAR AS PRESIDENT

$\begin{array}{lll}\text { K.G. McKenzie } & \text { AANS (Harvey Cushing Society) } & 1936-36 \\ \text { W. Penfield } & \text { Soc. Neurol. Surg. } & 1942-44 \\ \text { W.S. Keith } & \text { Amer. Acad. Neurol. Surg. } & 1947 \\ \text { K.G. McKenzie } & \text { Soc. Neurol. Surg. } & 1948-49 \\ \text { F. Turnbull } & \text { AANS (Harvey Cushing Society) } & 1949-50 \\ \text { E.H. Botterell } & \text { Amer. Acad. Neurol. Surg. } & 1950 \\ \text { A.R. Elvidge } & \text { Amer. Acad. Neurol. Surg. } & 1957 \\ \text { C. Bertrand } & \text { Neurosurg. Soc. Amer. } & 1962-63 \\ \text { T.B. Rasmussen } & \text { Amer. Acad. Neurol. Surg. } & 1964 \\ \text { W.H. Feindel } & \text { Amer. Acad. Neurol. Surg. } & 1976\end{array}$


YEAR AS PRESIDENT
NAME SOCIETY

C.G. Drake

C.G. Drake

R.R. Tasker

Amer. Acad. Neurol. Surg.

1977-78

1980-81

Soc. Neurol. Surg.

$1980-81$

and Functional Neurosurg.

H.J. Hoffman
Amer. Soc. Paediat.

Neurosurg. mental structure. The head of a department may look upon the diminution of his holding with distaste and advise against it. Non-clinical scientists scorn the non-scientific clinical method, and perceive its practitioners as favoured beyond their deserts. The difficulties in changing the status quo have been put down to an excess of democracy. The machinery of administration, originally designed to cherish excellence, may, by its pervasiveness, stifle initiative.

\section{REFERENCES}

\section{University Organization in the Neurosciences}

If ever there was a natural grouping, scientific and clinical, it is the neurological sciences. McGill, on advice from Penfield, understood this in the 1930s and acted on it. Why hasn't every Canadian university followed suit?

There is no substitute for physical proximity and daily conversation with colleagues in the same field. Yet the University of Western Ontario had to wait until 1969 before a Department of Clinical Neurological Sciences was sanctioned following representations by Drake and Barnett. Even their eloquence could not persuade their colleagues in the basic neurological sciences to join them. Fifteen years of memoranda and meetings passed before Kenneth Paine persuaded the University of Saskatchewan to create a similar Department of Clinical Neurological Sciences in 1977. Neurological scientists, basic and clinical, at the University of Toronto ten years ago recommended in vain that they should organize into one department.

The difficulty is not confined to the older schools. Maurice Héon, the first head of neurosurgery in 1968 at the new Université de Sherbrooke Medical School, was defeated in his attempt to unite at least the clinical departments of neurosurgery and neurology.

McGill is the only school to have united all neuroscientists, and that was fifty years ago. The Montreal Neurological Institute and Hospital, enlarged and intact, flourishes still.

The reasons for the failure of neuroscientists to bring about the administrative model they desire are many. University academic administrators do not like to disturb existing depart-
Archiblad EW (1908) Surgical affections and wounds of the head. In: Bryant JD and Beck AH (Eds): American Practice of Surgery. New York. William Wood \& Co.

Feindel W (1967) Highlights of neurosurgery in Canada. J. Amer. Med. Assoc. 200: 853-859.

Geisler WO, Jousse AT, Wynne-Jones $M$ and Breithaupt D (1983) Survival in traumatic spinal cord injury. Paraplegia $21: 364-373$.

Hay RK (1967) Neurosurgical aspects of traffic accidents: Report of a Sub-Committee of the Canadian Neurosurgical Society. Canad. Med. Assoc. J. 97: 1364-1368.

Ivan LP (1981) Time sequence in brain death. In: Morley TP (Ed). Moral, Ethical and Legal Issues in the Neurosciences. Springfield, Illinois. Charles $\mathrm{C}$. Thomas.

Lougheed WM, Bertrand G and Hay RK (1970) Paraplegic Care in Canada 1969. Report of a Sub-Committee of the Canadian Neurosurgical Soceity. Modern Medicine of Canada. March.

Millar A (1954) Lobotomy. A Clinical Study. Ontario Department of Health.

McKenzie KG (1960) In: The Opening of the Neurosurgical Unit, Toronto General Hospital, November 8, 1958. Morley TP (Ed). P. 25 University of Toronto Press.

McKenzie KG, Kaczanowski G. Prefrontal leukotomy: a five year controlled study. Canad. Med. Ass. J. 91: 1193-6. 5 December 1964.

Penfield WP (1976) No Man Alone. Boston/Toronto. Little, Brown \& Co: p. 319.

Robb P (1962) Submission to the Royal Commission of Health Services from the Canadian Neurological Society.

Royal Commission on Health Services (1964) Ottawa. Queen's Printer. Cat. no. Z1-1961/3-1.

Tator CH, Rowed DW, Schwartz ML. et al. (1984) Management of acute spinal cord injuries. Canad. J. Neurol. Sci. 27: 289-294.

Walshe FMR (1957) The brain stem conceived as the "highest level" of function in the nervous system; with particular reference to the "autonomic apparatus" of Carpenter and to the "centrencephalic integrating system" of Penfield. Brain 80: 510-539. 